UDC: $811.111^{\prime} 342.41$

\title{
THE MONOPHTHONGS OF TRADITIONAL COCKNEY AND POPULAR LONDON SPEECH IN CONTEXT
}

\author{
BRIAN MOTT ${ }^{1}$ \\ University of Barcelona, Faculty of Arts, \\ Department of English and German Studies, \\ Barcelona, Spain
}

Ovaj rad ispituje monoftonge tradicionalnog koknija proizvedene $u$ vezanom govoru tri starija muška ispitanika i upoređuje vrednosti F1 i F2 sa onima koje je za opšteprihvaćeni izgovor (eng. RP) izmerio Deterding, kao i sa vrednostima iz prethodnog eksperimenta sa istim tim ispitanicima $u$ pojedinačnim izolovanim rečima ( $u$ kontekstu /h_d/).

Ključne reči: kokni, engleska dijalektologija, engleski monoftonzi, engleska sociolingvistika, popularni govor Londona

\section{INTRODUCTION}

In its strictest sense, "Cockney" refers to the basilectal extreme of the popular speech of London, used in an imprecise area north of the River Thames referred to as the East End, whose traditional core neighbourhood is the present-day borough of Tower Hamlets. However, most of the time, the term "Cockney" is used loosely to include any working-class London accents that deviate noticeably from the standard (RP or SSB, as it is variously called). Among these, the varieties that are closer to RP might be more accurately termed Popular London Speech.

In a previous experiment (Mott 2012), I examined the pronunciation of the (relatively) pure vowels of Cockney in citation form in the context $/ \mathrm{h}$ _d/ and compared the results with those obtained for RP by Wells (1962) and Deterding (1997). Recordings were made of three men from London, aged 55,63 and 67 at the time of recording, reading the vowels in the context / $h$ _d/. Calculations of averages for the F1 and F2 of each of these vowels produced the following findings: 


$\begin{array}{ll}\text { Vowel } & \text { height and frontness compared to RP } \\ \text { FLEECE } & \text { lower, slightly fronter } \\ \text { KIT } & \text { similar in height, fronter } \\ \text { DRESS } & \text { higher, fronter } \\ \text { TRAP } & \text { higher, fronter } \\ \text { START } & \text { slightly higher, similar in frontness } \\ \text { LOT } & \text { very slightly lower, fronter } \\ \text { THOUGHT } & \text { slightly higher, similar in frontness } \\ \text { FOOT } & \text { similar in height, fronter } \\ \text { GOOSE } & \text { lower, fronter } \\ \text { STRUT } & \text { similar in height, fronter } \\ \text { NURSE } & \text { higher, fronter }\end{array}$

If we compare these results with previous observations made in the literature on the vowels of Cockney, we can say the following:

Regarding the кIт vowel, it is generally assumed that it can be more central in Cockney than in RP, but it was actually found to be fronter. The PALM vowel was not found to be fully back and low, as it may be in some Cockney accents, but slightly higher and similar in frontness to RP. The STRUT vowel was similar in height to RP and not lower, despite my anticipating a much lower articulation, as predicted in the literature, by using the symbol [a]. The Lot vowel was not found to be higher than in RP, as is often claimed, but very slightly lower and fronter.

\section{THE PRESENT STUDY}

The present study is a continuation of an earlier inquiry into the frequencies of the first two formants of the Cockney (relatively) pure vowels in citation form, whose results are summarized above. This study concentrates on the frequencies of the same vowels as pronounced by the same participants, but in connected speech. For the purpose of the exercise, they were asked to read the passage "The Boy who Cried Wolf" (adapted version by Deterding [2006: 193]), whose orthographic version and approximate RP transcription are provided below (3.1 and 3.2), together with a transcription of the version provided by one of the three readers (3.3). The words underlined in the orthographic version were those chosen to form the basis of the analysis of the vowel qualities.

The passage "The Boy who Cried Wolf" was chosen as more appropriate than "The North Wind and the Sun" to measure the English vowels for the reasons expounded in Deterding 2006, the most important being the many lexical repetitions in "North Wind", and the fact that some of the sounds of English are consequently absent from it. Moreover, although all of the English monophthongs are represented, the NURSE vowel occurs only in the form first, and there are rather a lot of pre-vocalic approximants (wind, were, which, was, when, warm, one, stronger, traveller, wrapped, around) which will lower the F2. In contrast, the Wolf passage has at least three clear instances of each of the monophthong vowels without neighbouring approximants. For my own study, I have chosen three tokens of each vowel from those listed by Deterding (2006: 194). 


\section{THE RECORDINGS}

The recordings, made on a Sony mini-disc recorder (MZ-R55) with a Sony electret condenser microphone (ECM717), were converted to wave files using Goldwave and transcriptions were produced. When it was necessary to check features such as aspiration, voice and glottalization, the relevant segments were examined in the programme PRAAT. To keep the transcriptions reasonably consistent, cases where laryngealization seemed to be present rather than complete glottal closure were all treated as cases of glottalization and the symbol for the glottal stop was used.

Nasalization of vowels is not indicated in the transcriptions. It is normal for vowels to be nasalized to a greater or lesser extent when followed by a nasal consonant, and this is particularly noticeable in Cockney and PLS. However, as it is a feature that is entirely predictable, it was considered unnecessary to record it in the phonetic notation.

\subsection{THE BOY WHO CRIED WOLF. ORTHOGRAPHIC VERSION}

There was once a poor shepherd boy who used to watch his flocks in the fields next to a dark forest near the foot of a mountain. One hot afternoon, he thought up a good plan to get some company for himself and also have a little fun. Raising his fist in the air, he ran down to the village shouting 'Wolf, Wolf.' As soon as they heard him, the villagers all rushed from their homes, full of concern for his safety, and two of his cousins even stayed with him for a short while. Ihis gave the boy so much pleasure that a few days later he tried exactly the same trick again, and once more he was successful. However, not long after, a wolf that had just escaped from the zoo was looking for a change from its usual diet of chicken and duck. So, overcoming its fear of being shot, it actually did come out from the forest and bean to threaten the sheep. Racing down to the village, the boy of course cried out even louder than before. Unfortunatelv as all the villagers were convinced that he was trying to fool them a third time, they told him, 'Go away and don't bother us again.' And so the wolf had a feast.

\subsection{THE BOY WHO CRIED WOLF. RP TRANSCRIPTION}

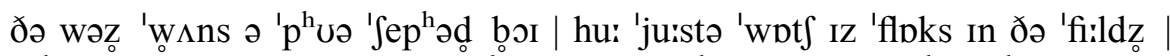

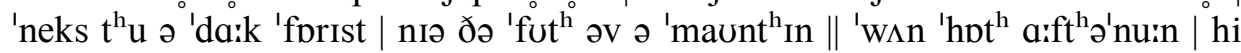

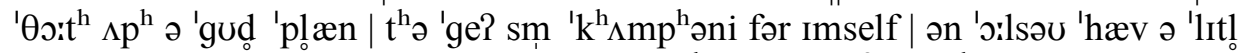

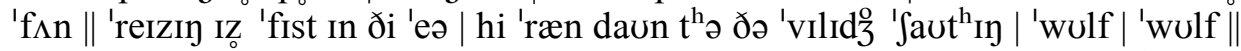

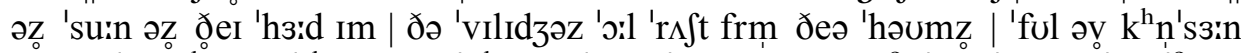

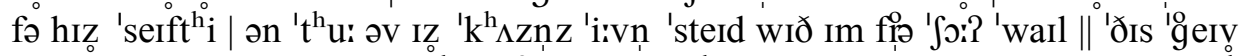

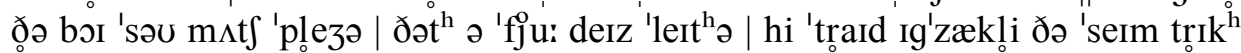
ว'gen | ən 'wıns 'mə: hi wəz sək'sesfl || hav'evə | 'np? lpy 'a:ft"

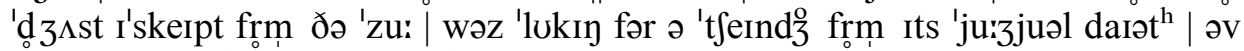

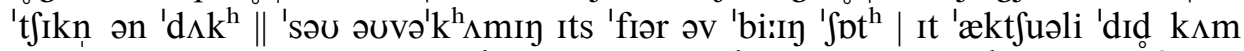

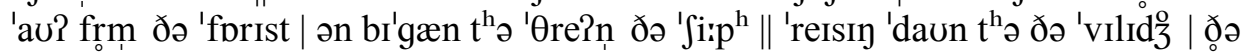

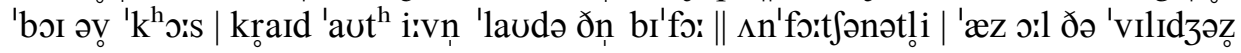




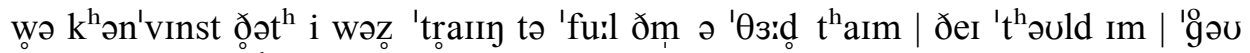

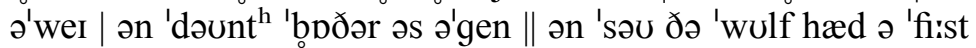

\subsection{THE BOY WHO CRIED WOLF. TRANSCRIPTION OF MALE COCKNEY SPEAKER (TS, AGED 63)}

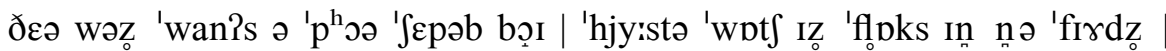

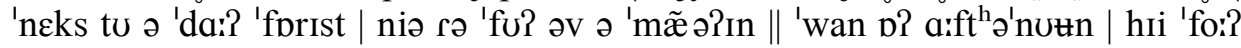

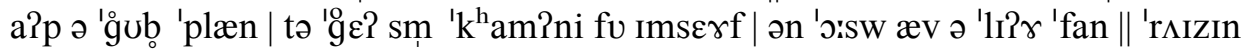
IZ 'fist In n

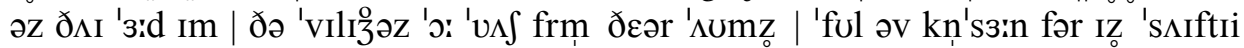
| æn 'th

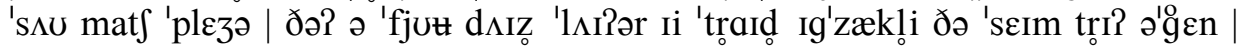

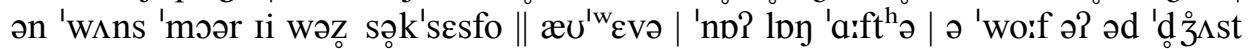

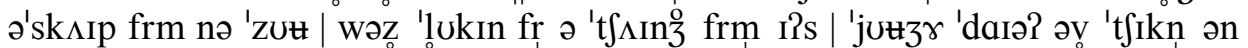

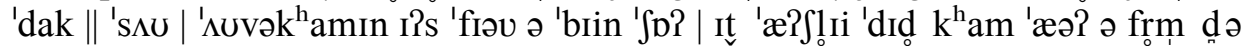

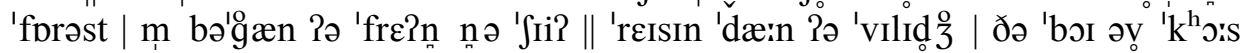

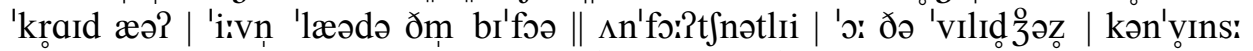

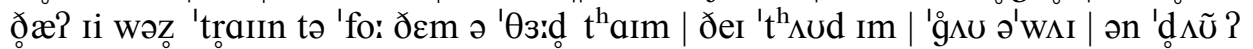
'bpvər əs ว่gen || ən 's 


\section{RESULTS}

The study outlined in this paper produced the results recorded in tabular form below.

\begin{tabular}{|c|c|c|c|c|c|c|c|c|c|c|c|}
\hline \multirow[t]{2}{*}{ Vowel } & \multirow[t]{2}{*}{$\begin{array}{l}\text { Word in } \\
\text { context }\end{array}$} & \multicolumn{2}{|c|}{$\begin{array}{l}\text { Steve Wood } \\
\text { age 55, } \\
\text { Deptford } \\
\text { (SE8) }\end{array}$} & \multicolumn{2}{|c|}{$\begin{array}{l}\text { Tony Corsini } \\
\text { age } 67, \\
\text { Paddington } \\
\text { (W2) }\end{array}$} & \multicolumn{2}{|c|}{$\begin{array}{c}\text { Tony } \\
\text { Saward } \\
\text { age 63, } \\
\text { Barnes } \\
\text { (SW13) }\end{array}$} & \multicolumn{2}{|c|}{$\begin{array}{l}\text { Averages } \\
\text { per word } \\
\text { for the } \\
\text { three } \\
\text { speakers }\end{array}$} & \multicolumn{2}{|c|}{$\begin{array}{c}\text { Global } \\
\text { averages }\end{array}$} \\
\hline & & F1 & F2 & F1 & F2 & F1 & F2 & $\mathrm{F} 1$ & $F 2$ & F1 & F2 \\
\hline \multirow{3}{*}{ 1. [ii] } & sheep & 419 & 2020 & 423 & 1865 & 483 & 1707 & 441 & 1864 & \multirow{3}{*}{383} & \multirow{3}{*}{2049} \\
\hline & even & 410 & 2243 & 279 & 2347 & 334 & 2170 & 341 & 2253 & & \\
\hline & feast & 382 & \begin{tabular}{|l|}
1941 \\
\end{tabular} & 325 & 2157 & 402 & 1998 & 369 & 2032 & & \\
\hline \multirow{3}{*}{ 2. [I] } & fist & 487 & 1980 & 351 & 1991 & 412 & 1617 & 416 & 1862 & \multirow{3}{*}{398} & \multirow{3}{*}{1904} \\
\hline & This & 412 & 2002 & 327 & 1892 & 444 & 1438 & 394 & 1777 & & \\
\hline & chicken & 402 & 2092 & 369 & 2015 & 382 & 2118 & 384 & 2075 & & \\
\hline \multirow{3}{*}{ 3. $[\varepsilon]$} & shepherd & 539 & 1722 & 465 & 1646 & 490 & 1691 & 498 & 1686 & \multirow{3}{*}{495} & \multirow{3}{*}{1717} \\
\hline & get & 541 & 1983 & 466 & 1928 & 457 & 1574 & 488 & 1828 & & \\
\hline & $\begin{array}{l}\text { success } \\
\text {-ful }\end{array}$ & 519 & 1691 & 505 & 1653 & 500 & 1568 & 500 & 1637 & & \\
\hline \multirow{3}{*}{ 4. [æ] } & exactly & 709 & 1791 & 810 & 1708 & 593 & 1607 & 704 & 1702 & \multirow{3}{*}{622} & \multirow{3}{*}{1598} \\
\hline & began & 576 & 2021 & 468 & 1597 & 563 & 1195 & 535 & 1604 & & \\
\hline & had & 644 & 1679 & 670 & 1560 & 569 & 1228 & 627 & 1489 & & \\
\hline \multirow{3}{*}{ 5. [a:] } & dark & 684 & 1157 & 576 & 1087 & 591 & 968 & 617 & 1070 & \multirow{3}{*}{621} & \multirow{3}{*}{1423} \\
\hline & & 602 & 1061 & 584 & 1085 & 609 & 1008 & 598 & 1051 & & \\
\hline & after & 701 & 1233 & 599 & 1000 & 648 & 1007 & 649 & 1080 & & \\
\hline \multirow{3}{*}{ 6. [p] } & flocks & 571 & 1037 & 553 & 920 & 555 & 993 & 559 & 983 & \multirow{3}{*}{569} & \multirow{3}{*}{1013} \\
\hline & & 645 & 975 & 477 & 839 & 611 & 1135 & 577 & 983 & & \\
\hline & bother & 596 & 956 & 643 & 1305 & 480 & 961 & 573 & 1074 & & \\
\hline \multirow{3}{*}{ 7. [0:] } & thought & 470 & 748 & 435 & 1081 & 432 & 782 & 445 & 870 & & \\
\hline & course & 580 & 625 & 373 & 695 & 459 & 858 & 470 & 726 & 148 & 69 \\
\hline & $\begin{array}{l}\text { Unfortun } \\
\text {-ately }\end{array}$ & 428 & 663 & 362 & 717 & 504 & 758 & 431 & 712 & & 169 \\
\hline & foot & 389 & 1170 & 432 & 1021 & 455 & 1095 & 425 & 1095 & & \\
\hline 8. $[u]$ & & 432 & 1061 & 331 & 1096 & 395 & 1282 & 386 & 1146 & 409 & 1184 \\
\hline & looking & 460 & 1308 & 359 & 1334 & 437 & 1297 & 418 & 1313 & & \\
\hline & Soon & 378 & 1613 & 308 & 1591 & 468 & 1655 & 384 & 1619 & & \\
\hline 9. [utr] & two & 412 & \begin{tabular}{|l|}
1319 \\
\end{tabular} & 334 & 1309 & 423 & 1453 & 389 & 1360 & 400 & 1529 \\
\hline & & 464 & \begin{tabular}{|l|}
1562 \\
\end{tabular} & 359 & 1555 & 463 & 1714 & 428 & 1610 & & \\
\hline & cousins & 644 & \begin{tabular}{|l|}
1272 \\
\end{tabular} & 687 & 1414 & 600 & 981 & 643 & 1222 & & \\
\hline 10. [a] & & 628 & 1226 & 553 & 1173 & 605 & 1140 & 595 & 1179 & 649 & 1265 \\
\hline & & \begin{tabular}{|l|}
716 \\
\end{tabular} & \begin{tabular}{|l|}
1386 \\
\end{tabular} & 729 & \begin{tabular}{|l|}
1471 \\
\end{tabular} & 683 & 1327 & 709 & 1394 & & \\
\hline & heard & 545 & 1350 & 510 & 1616 & 480 & 1032 & 511 & 1332 & & \\
\hline 11. [3:] & concern & 540 & \begin{tabular}{|l|}
1478 \\
\end{tabular} & 468 & 1374 & 453 & 1152 & 487 & 1334 & 499 & 1349 \\
\hline & third & 534 & 1343 & 484 & 1436 & 485 & 1367 & 501 & 1382 & & \\
\hline
\end{tabular}

Fig. 1. Cockney vowel frequencies based on three male speakers and three words per vowel 


\begin{tabular}{|c|c|c|c|c|c|c|c|c|c|c|}
\hline \multirow[t]{2}{*}{$\begin{array}{l}\text { Vowels } \\
\text { of } \\
\text { Cockney } \\
\text { and RP }\end{array}$} & \multicolumn{2}{|c|}{$\begin{array}{l}\text { Averages for } \\
\text { Cockney Vs } \\
\text { in citation } \\
\text { form }\end{array}$} & \multicolumn{2}{|c|}{$\begin{array}{c}\text { Figures from } \\
\text { Cruttenden } \\
\text { (Gimson) } \\
\text { for RP Vs in } \\
\text { citation form }\end{array}$} & \multirow[t]{2}{*}{$\begin{array}{l}\text { Observations } \\
\text { on Cockney } \\
\text { Vs in citation } \\
\text { form as } \\
\text { compared } \\
\text { to RP Vs in } \\
\text { citation form }\end{array}$} & \multicolumn{2}{|c|}{$\begin{array}{c}\text { Averages } \\
\text { for Cockney } \\
\text { Vs in } \\
\text { connected } \\
\text { speech }\end{array}$} & \multicolumn{2}{|c|}{$\begin{array}{l}\text { Figures from } \\
\text { Cruttenden } \\
\text { (Gimson) } \\
\text { for RP Vs in } \\
\text { connected } \\
\text { speech }\end{array}$} & \multirow[t]{2}{*}{$\begin{array}{c}\text { Observations } \\
\text { on Cockney Vs } \\
\text { in connected } \\
\text { speech as } \\
\text { compared } \\
\text { to RP Vs in } \\
\text { connected } \\
\text { speech }\end{array}$} \\
\hline & F1 & F2 & F1 & F2 & & F1 & F2 & F1 & F2 & \\
\hline /i:/ & 311 & 2389 & 275 & 2221 & $\begin{array}{l}\text { lower, slightly } \\
\text { fronter }\end{array}$ & 383 & 2049 & 280 & 2249 & $\begin{array}{c}\text { lower and } \\
\text { backer }\end{array}$ \\
\hline |I & 369 & 2221 & 382 & 1958 & $\begin{array}{l}\text { similar in } \\
\text { height, } \\
\text { fronter }\end{array}$ & 398 & 1904 & 367 & 1757 & $\begin{array}{l}\text { slightly lower, } \\
\text { fronter }\end{array}$ \\
\hline /e/ & 499 & 2048 & 560 & 1797 & $\begin{array}{l}\text { higher, } \\
\text { fronter }\end{array}$ & 495 & 1717 & 494 & 1650 & $\begin{array}{c}\text { similar in } \\
\text { height, slightly } \\
\text { fronter }\end{array}$ \\
\hline |æ| & 679 & 1825 & 732 & 1527 & $\begin{array}{l}\text { higher, } \\
\text { fronter }\end{array}$ & 622 & 1598 & 690 & 1550 & $\begin{array}{l}\text { slightly higher } \\
\text { and slightly } \\
\text { fronter }\end{array}$ \\
\hline /a:/ & 650 & 1075 & 687 & 1077 & $\begin{array}{l}\text { slightly } \\
\text { higher, } \\
\text { similar in } \\
\text { frontness }\end{array}$ & 621 & 1423 & 646 & 1155 & $\begin{array}{l}\text { slightly higher, } \\
\text { fronter }\end{array}$ \\
\hline $\mid \mathrm{p} /$ & 602 & 934 & 593 & 866 & $\begin{array}{l}\text { very slightly } \\
\text { lower, fronter }\end{array}$ & 569 & 1013 & 646 & 1047 & $\begin{array}{c}\text { higher, slightly } \\
\text { backer }\end{array}$ \\
\hline$|0:|$ & 437 & 650 & 453 & 642 & $\begin{array}{c}\text { slightly } \\
\text { higher, } \\
\text { similar in } \\
\text { frontness }\end{array}$ & 448 & 769 & 415 & 828 & $\begin{array}{c}\text { slightly lower, } \\
\text { backer }\end{array}$ \\
\hline$|v|$ & 391 & 1073 & 414 & 1050 & $\begin{array}{l}\text { similar in } \\
\text { height, } \\
\text { fronter }\end{array}$ & 409 & 1184 & 379 & 1173 & $\begin{array}{l}\text { slightly lower, } \\
\text { very slightly } \\
\text { fronter }\end{array}$ \\
\hline /u:/ & 387 & 1438 & 302 & 1131 & lower, fronter & 400 & 1529 & 316 & 1191 & $\begin{array}{l}\text { lower and } \\
\text { fronter }\end{array}$ \\
\hline$|\Lambda|$ & 709 & 1373 & 695 & 1224 & $\begin{array}{l}\text { similar in } \\
\text { height, } \\
\text { fronter }\end{array}$ & 649 & 1265 & 644 & 1259 & $\begin{array}{l}\text { similar in } \\
\text { height and } \\
\text { frontness }\end{array}$ \\
\hline |3:/ & 499 & 1452 & 513 & 1377 & $\begin{array}{l}\text { higher, } \\
\text { fronter }\end{array}$ & 499 & 1349 & 478 & 1436 & $\begin{array}{c}\text { slightly lower, } \\
\text { backer }\end{array}$ \\
\hline
\end{tabular}


Fig. 2. Cockney vowel formant frequency averages (stressed vowels) compared to formant frequencies for RP (relatively) pure vowels (in citation form and connected speech) given in Cruttenden 2008 (Gimson $7^{\text {th }}$ ed.), pp. 99-100, for male speakers in all cases. The figures given in Cruttenden (Gimson) 2008 are taken from Deterding 1997. No figures are given for $/ \partial /$, whose quality varies according to the phonetic environment, and whose average values may be taken to be equivalent to those for /3:/.

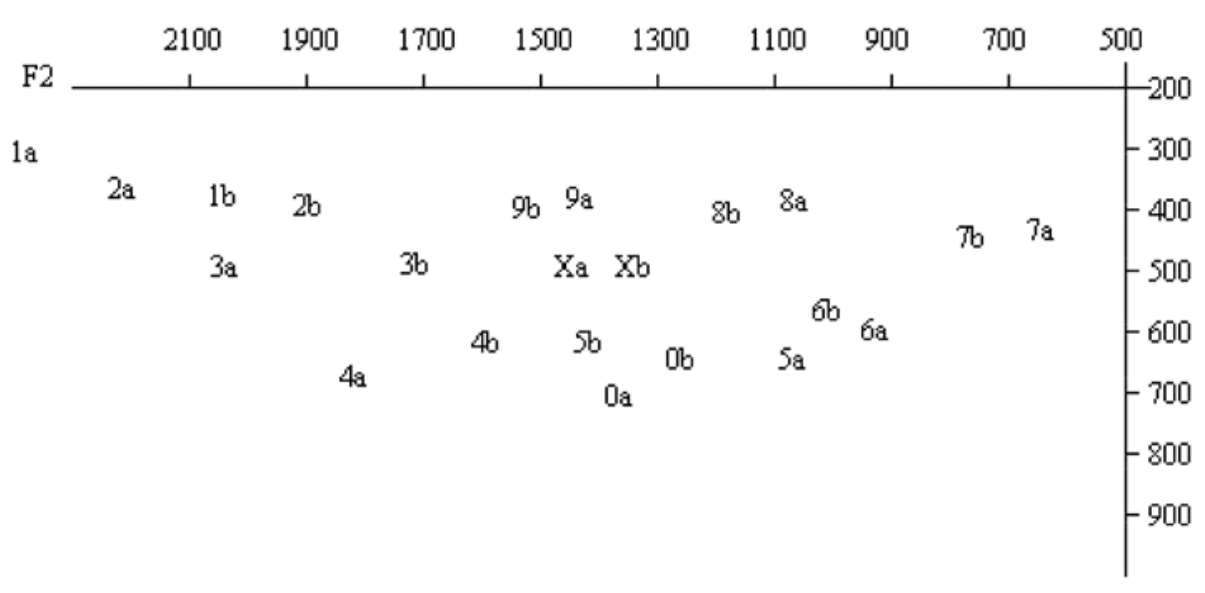

F1

Fig. 3. Cockney vowel formant chart: stressed vowels in citation form (1a, 2a, etc.) and connected speech $(1 b, 2 b$, etc.)

$$
\begin{aligned}
& 1=\text { FLEECE } 2=\text { KIT } 3=\text { DRESS } 4=\text { TRAP } 5=\text { START } 6=\text { LOT } \\
& 7=\text { THOUGHT } 8=\text { FOOT } 9=\text { GOOSE } 0=\text { STRUT } X=\text { NURSE }
\end{aligned}
$$

\section{CONCLUSION}

From fig. 2 we can see that the DRESs and sTRUT vowels are very similar in Cockney and RP in connected speech, while the FLEEcE and KIT vowels are slightly lower in Cockney. The open back vowels (START and LOT) are slightly higher than in RP, while the mid-high and close back vowels (тноиннт, ғоот and G0ose) are slightly lower. All this seems to point to greater centralization in Cockney than in RP, even though the frontness-backness variable shows some variation, with the Fо0т and Goose vowels both showing a strong tendency to front, like their RP counterparts.

Fig. 3 shows a consistent tendency for vowels in connected speech to be less peripheral than in citation form, as is to be expected. 


\section{REFERENCES}

Cruttenden, A. 2008. Gimson's Pronunciation of English. $7^{\text {th }}$ ed. London: Hodder Education.

Deterding, D. 1997. The formants of monophthong vowels in standard southern British English pronunciation. Journal of the International Phonetic Association 27, 47-55.

Deterding, D. 2006. The North Wind versus a Wolf: short texts for the description and measurement of English pronunciation. Journal of the International Phonetic Association 36/2, 187-196.

Mott, B. 2012. Vowel Frequencies in Traditional Cockney and Popular London Speech. In T. Paunović and B. Čubrović (eds.) Exploring English Phonetics. Newcastle upon Tyne: Cambridge Scholars Publishing, 3-12.

Wells, J. C. 1962. A Study of the Formants of the Pure Vowels of British English. M. A. dissertation, University College London. [Internet]. Available at: http://www.phon.ucl. ac.uk/home/wells/formants/index.htm [03.09.2011].

\section{SUMMARY}

\section{THE MONOPHTHONGS OF TRADITIONAL COCKNEY AND POPULAR LONDON SPEECH IN CONTEXT}

The paper examines the pure vowels of Traditional Cockney as pronounced in connected speech by three elderly male speakers and compares the F1 and F2 values with those obtained for RP by Deterding, and those from a previous experiment with the same speakers for the vowels in citation form (in the context $/ h_{-} d /$ ).

KEYWORDS: Cockney, English dialectology, English pure vowels, English sociolinguistics, Popular London speech.

(Original scientific paper received 03.09.2011;

revised 10.10.2011;

accepted 17.10.2011) 